\title{
Vigesimal Numerals on Ifẹ̀ (Togo) and Ifẹ̀ (Nigeria) Dialects of Yorùbá
}

\author{
Felix Abídèmí Fábùnmi (Ilé-Ifẹ̀)
}

\begin{abstract}
This study intends to bring Ifẹ̀ (Togo) into a linguistic limelight using the numeral systems. Numerals are a very important aspect of the day to day socio-economic and linguistic life of Ifẹ̀ (Togo) people. The traditional Ifẹ̀ (Togo) number system is vigesimal. In this study, fortytwo different number words are listed for Yorùbá Ifẹ̀ (Nigeria) and Yorùbá Ifẹ̀ (Togo) and compared with Standard Yorùbá. We compared the Ifẹ̀ (Togo) number words and counting patterns with that of the Standard Yorùbá and Ifẹ̀ (Nigeria) and discovered that, by the nature of the components of these numbers, majority of the basic number words are either bisyllabic or trisyllabic, each syllable having the form VCV for the cardinals, and CVCV for the ordinals. There are irregularities in tonality; there are also alternations in the sequences of the vowel (oral and nasalized) and consonant sounds. This work finds out that Ifẹ̀ (Togo) has two counting patterns. In the first pattern, it uses addition solely to derive the number words but with a counting pattern where 'ten', 'twenty' and the added number units are taken as a whole. In the second counting pattern, subtraction is used to derive number words but this is applicable only to three numbers i. e. seventeen - /méctadínógú/, eighteen - /méèçìdínógu/ and nineteen - /mòkõdínógu/. The Ifẹ̀ (Togo) dialect of Yorùbá mostly uses additive number positions. The dialect favours additive number positions more than the subtractive and the multiplicative positions. In other words, higher numbers are frequently used as bases for addition not as bases for multiplication in Ifẹ̀ (Togo). There are many linguistic variations in the number words employed by Ifẹ̀ (Togo) and Ifẹ̀ (Nigeria) dialects of Yorùbá, such variations can be attributed to changes in time and distance.
\end{abstract}

\section{Introduction}

The Yorùbá language belongs to the West Benue-Congo of the Niger-Congo phylum of African languages (Williamson/Blench 2000: 31). Majority of the speakers of the language reside in the Southwestern part of Nigeria with a population of about sixty million. There are about sixteen Universities in the United States where students learn Yorùbá (Adewole 2007:23). Yorùbá is regarded as one of the three major languages of Nigeria. So, any language like Yorùbá spoken by more than a handful of people exhibits the tendency to split into dialects which may differ from one another. We therefore see the diverse varieties of the Yorùbá language, used by groups smaller than the total community of speakers of the language within the geographical area, as dialects of the same language. But aside from Nigeria, the language is also spoken in countries like Republic of Bénin, Togo, Ghana, Cote D'ivoire, Sudan and Sierra-Leone. Outside Africa, a great number of speakers of the language 
are in Brazil, Cuba, Haiti, Caribbean Islands, Trinidad and Tobago, UK and America (Abimbola 1978: 2; Hunt 1977: 17, 51; Lasebikan 1963: 352; Turner 1958: 45; Walkins 1972: $380)$.

Dialectologists working on the Yorùbá language have identified about thirty-two dialectal varieties of the language (Awobuluyi 1998; Fábùnmi 2004, 2009). We observe, however, that Yorùbá dialectological study heavily concentrates on those dialects spoken in Nigeria alone; scholars have neglected those varieties whose speakers are located outside Nigeria. Among them are Mộfọ̀lí, Ifẹ̀ (Togo), Tsábẹ, Àjàsẹ́, Ìfọ̀hìn, Ìdáàtșà, Itsa and Mànígrì. All these are Yoruboid, the mother tongues of speech communities whose forefathers migrated from Nigeria to Dahomey, now Republic of Benin. They are communities speaking dialects descended from the same proto-language, proto-Defoid (Baloubi 2002). Since Koelle's Polyglotta Afrikana (1854), the Yorùbá dialects outside Nigeria are yet to be surveyed. This might have prompted Igue/Yai (1973: 2-3), while noting the trend as a defiance of history, to opine that "there are two types of Yorùbá: those in Nigeria and the others. The former are well known; it is enough simply to mention the existence of the latter [...] in the field of linguistics, the situation is hardly more encouraging." By this paper therefore, we intend to bring Ifẹ̀ (Togo), a Yorùbá Dialect spoken in Benin and Togo, into linguistic limelight.

\section{$2 \quad$ Yorùbá Dialectology}

One variety of Yorùbá, the Ọyọ́ dialect, has been in use for literary purposes since 1843. It has been the obvious choice for standardization because it serves as inter-dialectal communication. Although the Òyọ́ variety commands a wider social acceptability, we must sound a note of caution, following Raven's (1971: 42) assertion, that "no dialect is simply good or bad in itself; its prestige comes from the prestige of those who use it." Yorùbá language is a dialect continuum; we regard the so-called Standard Yorùbá (SY) as a part of the Yorùbá, it is not the Yorùbá language. And according to Capo (1980: 275), Yorùbá should "be viewed as a lect within the cluster, a lect socially defined, which has its distinctive characteristics."

Scholars like Délànọ́ (1958), Adetugbọ (1967, 1973), Oyèláràn (1976) and Awóbùlúyì (1998) have classified Yorùbá dialects into groupings, among them are Northwest Yorùbá (NWY), Southeast Yorùbá (SEY), Central Yorùbá (CY), Northeast Yorùbá (NEY) and Southwest Yorùbá (SWY). Yorùbá dialects spoken in East and Central Dahomey, now Republic of Benin, and in western parts of the Republic of Togo, are classified as belonging to the SWY dialect subgroup. In essence, Ifẹ̀ (Togo), the focus of this study, belongs to SWY group while Ifẹ̀ (Nigeria) which belongs to CY.

\subsection{Ifẹ̀ (Nigeria) Dialect of Yorùbá}

Ilé-Ifệ is regarded as the cradle of the Yorùbá; in today's parlance it is called the "source". Majority of the speakers of Ifẹ̀ (Nigeria) dialect reside in Ilé-Ifẹ̀. Yorùbá dialectologists believe that Ifẹ̀ (Nigeria) belongs to the Central Yorùbá (CY) dialect subgroup. All Yorùbá cities, towns and villages trace their origin to Ilé-Ifẹ̀ based on the oral tradition passed down from one generation to another. The dialect of the Yorùbá people of Ilé-Ifẹ̀ is called the Ifẹ̀ dialect; it is a community speaking dialect descended from Yoruboid. The Ifẹ̀ dialect speakers reside mainly in the Southwest of Nigeria but because we also have other speakers of Ifẹ̀ dialect elsewhere, we then decide to refer to Ifẹ̀ people in Nigeria as Ifẹ̀ (Nigeria), and Ifẹ̀ 
people in Togo and Benin as Ifẹ̀ (Togo). Although the Ifẹ̀ (Nigeria) dialect is not the choice of the Yorùbá language standardization, it, however, has primacy in the Yorùbá dialect cluster. In the field of linguistics, the Ifẹ̀ (Nigeria) dialect has a distinct syntactic structure, segment structure, sequence structure conditions, tone, phonological rules, reduplication, pronouns, pronominalization features and numeral systems.

All the Yorùbá people in Nigeria and outside Nigeria trace their historical origin to Ilé-Ifẹ̀ in Nigeria, their social structure, deities and basic customs and ceremonies are very much alike, yet they do not have a complete linguistic tie with Ifẹ̀ in Nigeria; they have diverse means of communication. They do not speak the Ifẹ̀ dialect of Nigeria, their supposedly indigenous original language. As a result, the Yorùbá people have about thirty six dialects forming the Yorùbá dialect cluster. There are instances where some Yorùbá cities adopt "Ifệ" as part of their city names; examples are Ifẹ̀wàrà, Ifẹ̀-ọ̀dàn, Ifệtẹddó, Ijẹ̀bú-Ifẹ̀ and Ifẹ̀ (Togo). Ijệbú-Ifẹ̀ and Ifẹ̀ (Togo) are discrete Yorùbá dialects while Ifẹ̀wàrà, Ifẹ̀-ọdàn, Ifẹ̀tẹ̀dó, can be regarded as the linguistic variations of the Ifẹ̀ (Nigeria) dialect of Yorùbá.

\subsection{Ifẹ̀ (Togo) Dialect of Yorùbá}

Most of the Yorùbá dialects in the Republic of Benin and Togo are known as "Èdèlanguages". Ifẹ̀ (Togo) is a Yoruboid language included in the Benue-Congo group of NigerCongo. Ifẹ̀ (Togo) is a variety of Yorùbá spoken in a territory astride both Benin and Togo. Today, the capital of Ifẹ̀ (Togo) is Atakpamẹ. The Ifẹ̀ (Togo) dialect of Yorùbá is spoken by approximately 90'000 people in Atakpame, the speakers stretch from the Benin boundary up to Atakpamẹ in Togo. Majority of these Ifẹ̀ settlers migrated from İjà-Òkú in former Dahomey into the Togolese territory and subsequently found the city of Atapkamẹ. According to Igue/Yai (1973: 20-21), Ifẹ̀ (Togo) speakers are "distributed among villages of Ș̣̣tí-Èpò, Ija-Òkú, Ìdùmẹ̀, Ộkánlàwọ́n and Ộtọlá, all of them situated along the western boundary of Dahomey". There are several other early settlers or ethnic groups in Atakpamẹ such as Fọn, Ewe, Aposo, Kabrelosso, Ketokoli, etc., but the people of Ṣẹtí, Jámà and İgbèríko are predominantly Ifẹ̀. Other Ifẹ̀ (Togo) villages where speakers of Ifẹ̀ (Togo) dialect are residing are Alábàtà, Okútayà, Ẹfujáyé, Alékà, Oko Aṣàde, Așoko Ayépadà and Yanmọsílẹ. According to Igue/Yai (1973), among the traditional Ifẹ̀ (Togo and Benin) chiefs are the Dòní of Atakpamẹ, the Olú-ìlú of Ìdùmẹ̀, the Olú-ìlú of Șẹtí-Èpò, etc.

The Ifẹ̀ (Togo) dialect of Yorùbá is closely related to another Yorùbá dialect known as Ìdáàtsà. According to Baloubi (2002: 560), "the speakers of Ìdáàtsà dialect live in the northern part of the former Zou Province, now called Département des Collines. They have very close ancestral relationship with the Yorùbá of Nigeria." The Ifẹ̀ (Togo) dialect has a significant number of loan words from Fọn Language. Moreover, due to prolonged contact with other Beninese languages, the Ifẹ̀ (Togo) dialect have borrowed substantial lexical and morphological items. Speakers of the Ifẹ̀ dialect in Togo and Benin are citizens and indigenous to Togo and Benin respectively, i. e. they have been residents in the two countries well before French and British colonisations. By origin, however, they are descent from Ilé- 
Ifẹ̀, they are bona fide descendants of Odùduwà. They are called by Ifẹ̀ name, their cultural and political organizations are in faultless harmony with the other Yorùbá people; their language is Yoruboid, which represents a western dialect (SWY) of the Yorùbá dialect cluster.

\section{$3 \quad$ Yorùbá Numerals}

A dialectological study of the Yorùbá numeral system would help us to explain aspects of linguistic complexity noticed among the Yorubá speaking people, and by implication, help us to understand the language situation in the entire Yorùbáland better. Data on numerals and number words are evidence demonstrating language diversity among the Yorùbá people. In examining the features of the Yorùbá language, it becomes necessary to look beyond the standard form into the dialects, for a better understanding of certain number words. Scholars in the language have been calling on researchers to start studying the dialects of Yorùbá for what new things the dialects may teach us about the Yorùbá language (cf. Awobuluyi 1992).

Although the Yorùbá language is one of the most intensively studied languages of Africa, information about its many dialects and counting systems remains paltry. In the area of dialectal numeral derivations, there is hardly any known study. Starting from Crowder (1843/1852), several Nigerian and non-Nigerian scholars have worked extensively on the various linguistic features of Yorùbá; they focused mainly on the general linguistic features that mark the so-called standard version of the language. If Yorùbá is a dialect, and the Ọyọ́ dialect is the choice of the Yorùbá language standardization, then the present number words that are used for counting in the language are that of the Òyọ́ variety. It will then be of a great advantage if the numeral systems of other varieties of the same Yorùbá language are examined. We believe that every dialectal variety of Yorùbá is in itself a legitimate form of the language.

The complexity of derivation in Yorùbá numerals involves very cumbersome and complicated manners of multiplication, addition and subtraction. This may be simplified if they are made to undergo a process of adaptation in line with dialectal derivations. For instance, there are elaborate details on Yorùbá numerals as provided in Johnson (1921: i-iv), Abraham (1958: xxxii-xli) and Oyetade (1996: 21-22). For instance, according to Oyetade (1996: 22), the following represents the pattern of the traditional Yorùbá vigesimal number system:

One to ten are basic words and eleven to fourteen is expressed as $1+10,2+10,3+10$ and $4+$ 10 respectively. Fifteen to nineteen are expressed as $20-5,20-4,20-3,20-2,20-1$ and twenty "ogún" is a basic word. Twenty-one to twenty-four are expressed as $20+1,20+2,20+$ 3 and $20+4$. Twenty-five to twenty-nine are expressed as $30-5,30-4,30-3,30-2$ and $30-$ 1. Thirty "ogbọ̀n" is another basic word. A pattern similar to the one above is followed for thirty-one to thirty-four and thirty-five to thirty-nine. Forty "ogójì" from ogún + èjì is expressed as $20 \times 2$. The pattern of addition of 41 to 44 and subtraction for 45 to 49 is followed for numbers after fifty, sixty, seventy, eighty, etc. Fifty, àádọ́ta (ệwádọ́ta in Ifẹ̀ dialect), is 60 - 10. This pattern is followed for àádọ́rin - 70 (80 - 10), àádọ́rùn-ún - 90 (100 - 10), àádộâ - 110 (120 - 10), àádóje - 130 (140 - 10), àádọjọ - 150 (160 - 10), àádọ́sàn-án - 170 (180 - 10), and àádộaà - 190 which is also expressed as igba-dín-mẹ́wàá, or mẹ́wàá-dín-nígba (200 - 10). The pattern of multiplication used for forty is followed for 60 - ogọ́ta $-20 \times 3,80$ - ọgọ́rin $-20 \times 4$, 100 - ogọ́rùn-ún - $20 \times 5,120$ - ọgộà - $20 \times 6,140$ - ogóje - $20 \times 7,160$ - ogọ́jọ $20 \times 8,180$ - ọọ́sàn-án - $20 \times 9$ and another basic word, igba is used for 200 . 


\section{The Data}

Apart from English, we will attempt to provide the vigesimal numerals system in three different Yorùbá dialects, these are the Yorùbá Ọyọ́ which forms the standard variety, the Yorùbá Ifẹ̀ in Nigeria and the Yorùbá Ifẹ̀ in Togo. The last one can even be referred to as Yorùbá Ifẹ̀ in Togo and Benin, as we have stated earlier that Ifẹ̀ (Togo) is a variety of Yorùbá spoken in a territory astride both Benin and Togo. In this study, forty-two different number words are listed for Yorùbá Ifẹ̀ (Nigeria) and Yorùbá Ifẹ̀ (Togo) and compared with standard Yorùbá. These number words are the basic number words, i. e. one to ten, eleven to twenty, twenty one to twenty-nine, thirty, forty, fifty, sixty, seventy, eighty, ninety, one hundred, two hundred, four hundred, one thousand, two thousand and three thousand. The number words and vocabularies were collected by the use of the Ìbàdàn four hundred basic word-list.

\section{$5 \quad$ Basic Vigesimal Numerals in Ifẹ̀ (Togo) and Ifẹ̀ (Nigeria)}

The basic number words for one to ten in Ifẹ̀ (Nigeria) and Ifẹ̀ (Togo) are presented in table (1) below.

\begin{tabular}{|c|c|c|c|c|c|c|}
\hline \multirow{2}{*}{$\begin{array}{l}\text { English } \\
\text { (1) One }\end{array}$} & \multicolumn{2}{|c|}{ Standard Yorùbá } & \multicolumn{2}{|c|}{$\begin{array}{l}\text { Yorùbá Ifẹ̀ (Nigeria) } \\
\text { (VP-Derived Ordinal } \\
\text { Numerals) }\end{array}$} & \multicolumn{2}{|c|}{$\begin{array}{l}\text { Yorùbá Ifẹ̀ (Togo) } \\
\text { (VP-Derived Ordinal } \\
\text { Numerals) }\end{array}$} \\
\hline & ěñ̃/ว̀kã & ménĩ & iní & míní & દ̀ne/ડ̀k $\hat{c}$ & méné \\
\hline (2) Two & èđjì & méđjì & èđjì & méèđjì & èđbì & méèđjì \\
\hline (3) Three & غ̀tā & métā & ètā & méc̀tā & ètā & méctā \\
\hline (4) Four & غ̀r̂̂̀ & mé rî & èrî & méèrî & غ̀r ${ }^{\prime \prime}$ & méعré \\
\hline (5) Five & àrũ & márũ-ũ & غ̀rû́ & méc̀rú & غ̀rú & mécrú \\
\hline (6) Six & દ̀fâ & méfâ & غ̀fâ & méčfâ & દ̀fâ & mécfà \\
\hline (7) Seven & èdze & méçe & ème & méède & edze & méegुe \\
\hline (8) Eight & غ̀ḑo & médつ & 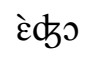 & méčḑ & غ̀ḑ & mécळౌ \\
\hline (9) Nine & غ̀sã & mésã-ã & غ̀sã & méc̀sã & Esâิ & mesẫ \\
\hline (10) Ten & غ̀wá & méwàá & غ̀wā & méc̀wā & maa & maja \\
\hline
\end{tabular}

Table 1

From (1) above, we are able to note that the numerals in the standard Yorùbá (SY henceforth), the Yorùbá Ifẹ̀ (Nigeria) (YIN henceforth) and Yorùbá Ifẹ̀ (Togo) (YIT henceforth) appear to have undergone a lot of changes. For instance, the basic words for one to ten in (1) above have different number words from the three different dialects of the language. The nature of the components of these numbers reveals that majority of them are bisyllabic, each syllable having the form VCV for the cardinals, and CVCV for the ordinals. The basic numbers one to ten in YIN and YIT are not significantly structurally different to those of SY, but there are irregularities in the low tone initial vowels. In SY and YIN, there are similarities in terms of the quality of tone, the consonant, and the vowel components. There are two ways of expressing 'one' in SY (ĕnĩ/ว̀kã), but YIN has only one word for it (iní). However, there are

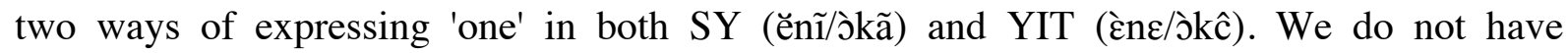


instances of a nasalized vowel at the initial syllable position in the three dialects, but the last syllables for 'one' in both SY and YIT end with a nasalized vowel. If we compare ěnĩ (SY), iní (YIN) and غ̀ne (YIT), we will observe that there is an alternation in the sequence of the vowel sounds, as shown in (2):

$/ \check{\mathrm{e}} / \quad \rightarrow \quad / \mathrm{i} / \quad \rightarrow \quad / \grave{\varepsilon} /$

The phonological process which regularizes sound alternation as in (2) above is known as metathesis. The number words for 'two' (èołì), 'three' (ètā), 'six' (èfâ), 'seven' (èdge) and 'eight' (غ̀do) in the three dialects are the same. This corroborates the claim that speakers of the Ifẹ̀ (Togo) dialect of Yorùbá were originally from Ilé-Ifẹ̀ before they migrated, striding many territories in former Dahomey and Togo, and finally settled in the "eastern edge of the massif of the "Monts Fetiches" at the foot of which nestles the town of Atakpamẹ." (Igue/Yai 1973: 20).

There is a syllabic nasal in the number word for 'nine' (غ̀sã) in SY, YIN and YIT but the nasalized vowel in that of YIT carries a mid tone - (Esẫ). The difference between the form for 'ten' in SY and YIN illustrates the type of tonal variation (high - mid) witnessed among Yorùbá dialects. But the number word for 'ten' in YIT (maa) stands out: it has a consonant initial syllable not a vowel initial syllable as in SY and YIN, it varies in the representation of tone - it has a mid-mid tonal variation as opposed to low - high tones of SY and YIN. This number word [maa] 'ten' does not appear to bear any similarity to any of the Yorùbá dialect groupings in Northwest Yorùbá (NWY), Southeast Yorùbá (SEY), Central Yorùbá (CY), and Northeast Yorùbá (NEY) except those in the Southwest Yorùbá (SWY) subgroup. Among the Yorùbá dialects in SWY are Mộfộlí, Ifẹ̀ (Togo), Tsábẹ, Àjàsẹ́, İfọ̀hìn, İdáàtṣà, Itsa, Àjàsẹ́ and Mànígrì. As shown in (3), there are obvious similarities in the number words for 'ten' among these SWY dialects.

\begin{tabular}{|c|c|c|c|c|c|}
\hline English & $S Y$ & Ifệ (Togo) & İdáàtșà & Tsábe & Itsa \\
\hline 10 (ten) & Èwá & maa & maa & Ewá & Èyá \\
\hline
\end{tabular}

Table 3

We opine that there is the possibility of a velar approximant [w] being dropped in 'maa' which indicates 'ten' in Ifẹ̀ (Togo) and Ìdáàtsà. It could have been realized as 'mawa' (ten) if it was retained, and this would have some phonological resemblance with 'méwàá' (ten) in SY or 'mécwā' (ten) in YIN. It is however revealed in the data presented in (1) that the ordinal numeral for 'ten' in YIT is 'maja'. In other words, where SY has a velar approximant [w] as a phoneme, YIT replaces it with a palatal fricative [j].

The data presented in (1) above also indicates that there are similarities in YIN and YIT ordinal numbers one to ten. The difference in the forms for 'one' - míní/méné is vowel /i/ and $/ \varepsilon /$ alternation, the $\mathrm{H}-\mathrm{H}$ tonal variation is retained. We see a pattern of vowel length or vowel quality in the number words for 'two' to 'eight' in YIN and YIT, there is a degree of similarity in respect to these numbers; but what we have in SY is a clear opposite. We also note that

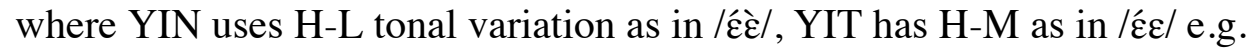


and Ifẹ̀ (Nigeria) Dialects of Yorùbá

\begin{tabular}{|c|c|c|}
\hline English & Ifẹ̀ (Nigeria) YIN & Ifệ (Togo) YIT \\
\hline 3 (three) & méc̀tā & méctā \\
\hline 4 (four) & méèrî & mécré \\
\hline 5 (five) & méc̀rú & mécrú \\
\hline $6(\operatorname{six})$ & méc̀fà & mécfà \\
\hline 7 (seven) & méèçe & méedze \\
\hline 8 (eight) & méc̀ḑo & mécḑo \\
\hline
\end{tabular}

Table 4

We have been analyzing the basic number words one to ten in SY, YIN and YIT; we shall now introduce the derivational vigesimal numeral in these Yorùbá dialects.

\subsection{Vigesimal Numeral Derivation in Ifẹ̀ (Togo) and Ifẹ̀ (Nigeria)}

The traditional YIN and YIT number system is vigesimal. It is vigesimal because the two dialects employ a numeral structure where counting is done in multiples of ogún 'twenty', igba 'two hundred', egbàa 'two thousand', etc. The vigesimal counting is reckoned in units of number twenty. It involves a lot of mathematical processes such as multiplication, addition and subtraction. Rowland (1969: 105-111) divides the numerals into four groups. He says "the first group is the one used in counting. The second is the 'total form' derived from a basic form." In other words, the 'total forms' are different from the basic ones because they are derived. The linguistic competence of the Yorùbá native speakers is at play here; according to Ekundayọ (1986: 9), this is "necessary for the construction, perception and syntactic representation of the infinite set of sentences in Yorùbá." To derive the numerals from eleven to twenty and upward, SY, YIN and YIT speakers employ addition to and subtraction from vigesimal and other units, as well as multiplication. The basic number words for eleven to twenty in Ifẹ̀ (Nigeria) and Ifẹ̀ (Togo) are presented in table (5) below.

\begin{tabular}{|c|c|c|c|}
\hline English & Standard Yorùbá & Ifệ (Nigeria) YIN & Ifẹ̀ (Togo) YIT \\
\hline (11) Eleven & mòkãlá & mĉ̀̀kãlá & maá ว̀k̃̃ \\
\hline (12) Twelve & médiìlá & méèojìlá & maá méèojì \\
\hline (13) Thirteen & métālá & méc̀tālá & maá mécta \\
\hline (14) Fourteen & mérîlá & méèrîlá & maá mécré \\
\hline (15) Fifteen & méčćdógú & méc̀dogú & medógú \\
\hline (16) Sixteen & mérîdîlógú́ & méèrîuîlógû́ & maá méc̀fà/medógú òyu òkã \\
\hline (17) Seventeen & métàdîlógú́ & méčtàdîlógú́ & maá méeḑe/méctadìnógú \\
\hline (18) Eighteen & méḑìdîlógú & méèdgìdîlógú́ & maá meḑొ/méèdìdínógú \\
\hline (19) Nineteen & mòkãdîlógú & mĉ̀̀kãdîlógú & maá mesã́/mòkõdínógú \\
\hline (20) Twenty & ogṹ & ogú & ogú \\
\hline
\end{tabular}


The SY, YIN and YIT numeral systems demonstrate the creativity in human language. The vigesimal system of Yorùbá tasks the comprehension skill of the speakers and hearers; it requires a series of cognitive processes. The speaker uses his/her internalized rules to derive the numerals in various ways. For instance in (5) above, the number words for 'eleven' to 'twenty' in SY show a similarity to those of YIN except in vowel length and vowel quality as in:

$\begin{array}{lll}\text { é } & \rightarrow & \text { éè } \\ \hat{\varepsilon} & \rightarrow & \varepsilon \hat{\varepsilon} \\ \grave{\partial} & \rightarrow & \text { ĉ̀̀ }\end{array}$

The only exception to (6) is the form for 'fifteen' in SY - /méżédógú/. Most importantly, the idea expressed in SY and YIN in (5) above is $1+10,2+10,3+10,4+10$ for eleven to fourteen; and 20 - 5, 20 - 4, 20 - 3, 20 - 2, 20 - 1 for fifteen to nineteen; twenty (ogún) is a basic word. But this pattern is completely different in YIT when compared to those of YIN or SY. As shown in (5) YIT has two counting patterns. In the first pattern, it uses addition solely to derive the number words but with a counting system where 'ten' the basic number, the added number (one to nine) are taken as a whole. The second one only complements the first one. In the second counting pattern, subtraction is used to derive the number word; this second method is applicable to only three numbers i. e. seventeen - /méctadìnógu/, eighteen /méègìdínógú/ and nineteen - /mòkõdínógú/. Most importantly, it is restricted to the speech of the older generation of Ifẹ̀ (Togo) speakers, the younger speakers prefer the first counting method because it is easier, it does not task their brain.

The numeral system of the Yorùbá language is endangered. Some Yorùbá scholars have therefore postulated various methods by which the numerals system of the language could be made more "friendly" and less cumbersome to the users. The rationale behind this is that the present generation of speakers of the language, most especially elites and teenagers are dropping the language's vigesimal system for the English decimal system. So, they proposed the counting system in the language to be something like (7):

\begin{tabular}{|c|c|}
\hline Numbers & New Counting \\
\hline 10 & ẹ̀wá kan \\
\hline 20 & ẹ̀wá méjì \\
\hline 30 & ẹ̀wá mẹ́ta \\
\hline 100 & ogọ́rùn-ún kan \\
\hline 200 & ogoọrùn-ún méjì \\
\hline 300 & ogộrùn-ún mẹ́ta \\
\hline 1000 & ẹgbẹrún \\
\hline 2000 & ẹgbẹ̀rún méjì \\
\hline 20000 & ẹgbẹ̀rún ogún \\
\hline $900^{\prime} 000$ & ẹgbẹ̀rún mẹ́wàá mẹ́sàn-án \\
\hline $10^{\prime} 000$ & ẹgbẹ̀rún mẹ́wàá \\
\hline $100^{\prime} 000$ & ẹgbẹ̀rún ọgọ́rùn-ún \\
\hline $1^{\prime} 000^{\prime} 000$ & ẹgbẹ̀rún ẹgbẹ̀rún \\
\hline
\end{tabular}

Traditional Counting
ẹ̀wá
ogún
ogbọ̀n
ogộrùn-ún
igba
ọộdúnrún
ẹgbẹ̀rún
ẹgbàá
ọ̀kẹ́ kan
ọ̀kẹ́ mẹ́rin ààbọ
ẹgbàarùn-ún
ọ̀kẹ́ márùn-ún
àádọ́ta ọ̀kẹ́

ẹ̀wá$$
\text { ogbò̀n }
$$

ogộrùn-ún

igba

dûnrún

ẹgbàá

ọ̀ẹ́ kan

ọ̀ké mẹ́rin ààbò

ọkẹ́ márùn-ún

aấdộta ộkẹ

The data shown in (5) above testifies to the fact that while the new proposal in (7) is still being ardently debated, speakers of YIT have already dropped the traditional vigesimal 
counting and adopted this new counting pattern. As a result, majority of them now use the pattern shown in (8) below.

\begin{tabular}{|c|c|c|c|c|}
\hline 11 & maá ว̀k̃̃ & $\rightarrow$ & ẹ̀wá kan & ten one \\
\hline 12 & maá méèḑì & $\rightarrow$ & ẹ̀wá méjì & ten two \\
\hline 13 & maá mécta & $\rightarrow$ & è̀wá mẹ́ta & ten three \\
\hline 14 & maá mécrě & $\rightarrow$ & ẹ̀wá mẹ́rin & ten four \\
\hline 16 & maá mécfà & $\rightarrow$ & ẹ̀wá mẹ́fà & ten six \\
\hline 17 & maá méeḑe & $\rightarrow$ & ẹ̀wá méje & ten seven \\
\hline 18 & maá mécḑo & $\rightarrow$ & ẹ̀wá mẹ́jọ & ten eight \\
\hline 19 & maá mesã́ & $\rightarrow$ & ẹ̀wá mẹsàn-án & ten nine \\
\hline
\end{tabular}

What we have in (8) is a simplified version of SY and YIN numerals (already shown in (5)) which, following Awúbùlúyì (2008: 102), have the following derivation:

(9)

$\begin{array}{lllll}11 & \text { mòkãlá } & \rightarrow & \text { mú ọ̀kànlá } & \text { take eleven } \\ 12 & \text { méçìlá } & \rightarrow & \text { mú èjilá } & \text { take twelve } \\ 13 & \text { métālá } & \rightarrow & \text { mú ẹ̀tàlá } & \text { take thirteen } \\ 14 & \text { mérîlá } & \rightarrow & \text { mú ẹ̀rìnlá } & \text { take fourteen } \\ 17 & \text { métàdîlógú } & \rightarrow & \text { mú ẹ̀tàlélógún } & \text { take seventeen, etc. }\end{array}$

The cognitive process in (9) is very complex while that of (8) is simpler. We believe that 'mú' (take) should not be introduced with the numerals as shown in (9) above, instead 'mọ́' (plus) is more appropriate. The idea of 'mú' (take) comes in because the numerals usually occur in imperative constructions. But since they imply addition i. e. plus eleven, plus seventeen, etc., then 'mọ́' (plus) should be more appropriate.

In the number words for 'fifteen' and 'twenty' in SY, YIN and YIT, shown in (5) above repeated as (10) below, we see a clear pattern of relationship confirming the belief that the three dialects are all Yoruboid.

(10) SY: méc̀édógṹ (fifteen), ogú (twenty)

YIN: méc̀dogṹ (fifteen), ogú (twenty)

YIT: medógú (fifteen), ogú (twenty)

If we examine YIT new pattern of counting presented in (5) and (8) above, we will observe that YIT number word for 'fifteen' in (10) does not conform to the new pattern. Following what we have in (8), 'fifteen' in YIT should follow the pattern shown in (11) below.

(11) 15 maá méc̀rú $\rightarrow$ ẹ̀wá márùn-ún - 'ten five'

The SY, YIN and YIT number words for 'fifteen' shown in (10) are cases of vowel alternation $[\hat{\varepsilon}] /[\mathrm{e}]$, consonant elision (/W/ has been dropped in mọ ệwá dín àrún dín ní ogún - (plus ten minus five minus twenty) i.e. méčćdógṹ), vowel assimilation $(0-\hat{\varepsilon}=\hat{\varepsilon})$ and vowel

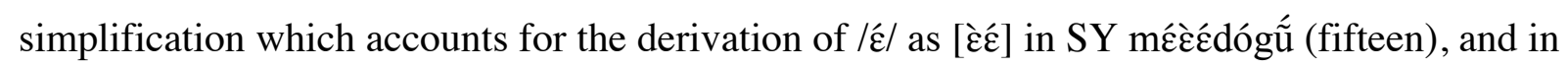
YIN méżdogú (fifteen) respectively. The form, which is given as the number word for 'twenty' in these dialects, is [ogṹ/ogú]. The last vowel in SY [ogú] corresponds to YIN [ogú], but it is 
different in YIT where we have an oral vowel as the last vowel in [ogú] instead of a nasalized vowel. 'Twenty' is another basic number word.

\subsection{The Numeral Unit of Twenty in Ifẹ̀ (Togo) and Ifẹ̀ (Nigeria)}

'Twenty', as a basic number word, ends the pattern 20 - 5 'five from twenty', 20 - 4 'four from twenty', etc. It begins another pattern which is essentially multiplication. The number words based on twenty upward in Ifẹ̀ (Nigeria) and Ifẹ̀ (Togo) are divided into two, for the purpose of our analysis, and are presented as (12) and (13) below.

\begin{tabular}{|c|c|c|c|}
\hline English & Standard Yorùbá & Ifẹ̀ (Nigeria) YIN & Ifẹ̀ (Togo) YIT \\
\hline (21) Twenty-one & ̀̀kãlélógṹ & ̀̀kãlélógû́ & òkãlénógú \\
\hline (22) Twenty-two & èđjìlélógú & èđìlélógú & èdzilénógú \\
\hline (23) Twenty-three & غ̀tàlélógû́ & غ̀tàlélógṹ & ètālénógú \\
\hline (24) Twenty-four & غ̀rîlélógú & èrîlélógú & غ̀rêlénógú \\
\hline (25) Twenty-five & èćdćgb̃̃ & èédćgbõ & Èrúlénógú \\
\hline (26) Twenty-six & غ̀rîdîlćgbõ & èrîdîlćgbõ & عfâlénógú \\
\hline (27) Twenty-seven & c̀tàdîlćgbõ & ètàdîlćgbõ & eđzelénógú/ctadínćgbãwó \\
\hline (28) Twenty-eight & èđłìdîlćgb̃̃ & èḑìîlćgbõ & 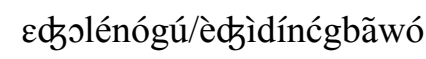 \\
\hline (29) Twenty-nine & òkãdîlćgbõ & j̀kãdîlćgbõ & عsắlénógú/s̀kãdínćgbãwó \\
\hline (30) Thirty & ogbõ & ogbõ & ćgbãwó \\
\hline
\end{tabular}

Table 12

\begin{tabular}{|c|c|c|c|}
\hline English & Standard Yorùbá & Ifẹ̀ (Nigeria) YIN & Ifẹ̀ (Togo) YIT \\
\hline (40) Forty & ogóđ̧ì & ogóòţì & ogóòtbì \\
\hline (50) Fifty & àádćtā & Èwádòta & maá lé nógóòđì̀ \\
\hline (60) Sixty & ogćtā & ogćòtā & ogóòtā \\
\hline (70) Seventy & àádćrĩ & غ̀wádòrĩ & maá lé nógóòta \\
\hline (80) Eighty & ogćrĩ & ogóòrĩ & ogóòre \\
\hline (90) Ninety & àádćrũ-ṹ & Èwádòrú & maá lé nógóòré \\
\hline (100) One Hundred & ogćrû́-ṹ & ogćòrú́ & ogóòrú \\
\hline (200) Two Hundred & igbā & igbā & igbóo \\
\hline (400) Four Hundred & irĩwó & irú & igbóo méèdjì \\
\hline (1000) One Thousand & عgbèrú̃ & عgbèrû́ & egbèrú \\
\hline (2000) Two Thousand & Egbàá/ Egbèwá & Egbàá & عgbèrú méèđì \\
\hline (3000)Three Thousand & عgbèćdógû́ & Egbèdógú́ & عgbèrú méc̀tā \\
\hline
\end{tabular}

Table 13 
In (12), SY and YIN have almost the same number words, using the same counting pattern of $20+1=21$, etc., for twenty-one to twenty-four and $30-5=25$, etc., for twenty-five to twenty-nine. But YIT does not strictly follow this pattern: the number words for twenty-one to twenty-nine in YIT are of the pattern $20+1=21,20+2=22,20+8=28,20+9=29$, etc.; not $30-2=28,30-1=29$, etc. In essence, YIT does not employ subtraction from vigesimal in its numeral derivation; rather it employs addition to the vigesimal. This YIT counting pattern is found mostly in the speech of the young ones and the elites. This group prefers a simpler numeral derivation which does not require much cognitive competency. The numeral system is a mathematical notation with the operations of arithmetic (addition, subtraction, multiplication and division). Arithmetic is much easier in the earlier additive positions. So, YIT uses additive positions. A closer examination of the number words for 'twenty-seven', 'twenty-eight' and 'twenty-nine' in (12) again shows that there are alternative number words for them i. e. /عtadínćgbãwó/ (27), /èçìínćgbãwó/ (28) and /òkãdínćgbãwó/ (29). Here, the subtractive position is used. But we discovered that this pattern has been confined mostly to the speech of members of the older generation. A large percentage of YIT speakers cannot comprehend them. They more often than not use the additive positions. It should be pointed out that even the YIT older speakers do not employ the alternative subtractive number words for 'twenty-five' and 'twenty-six,' instead they also use /Èrúlénógú/ $(20+5=25)$ and /عfâlénógú/ $(20+6=26)$ which SY and YIN speakers will consider as strange. In (12) above, we also see cases of [1] versus [n] alternation in YIT number words, it appears as a regular process in the vigesimal derivation of 'twenty-one' to 'twenty-nine'. 'Thirty' is another basic number word.

The number words for 'thirty' [ogb̃̃] in SY and YIN are the same, but it is slightly unrelated to that of YIT which is [ćgbãwó]; while SY/YIN is bi-syllabic, that of YIT is made up of three

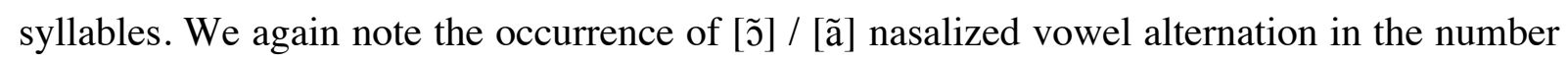
word for 'thirty'. Furthermore, ćgbãwó (thirty) is a derived compound noun; ogb̃ (thirty) is not a derived noun. From ćgbãwó we could derive (14) below.

$$
\begin{array}{lll}
\begin{array}{l}
\text { ćgbã } \\
\text { thirty }
\end{array} & \begin{array}{l}
\text { owó } \\
\text { cowry }
\end{array} & =\begin{array}{l}
\text { ćgbãwó } \\
\text { thirty-money }
\end{array}
\end{array}
$$

The initial vowel of the head noun in (14) has been elided. We do not see any other instances in YIT numerals where 'owó' (cowry) is added to the number words; in other words, there is nothing like (15) in YIT vigesimal numerals.
(a) ogú + owó $=$ *ogúwó
(twenty-money)
(b) ogóòđ̧ì + owó $=$ *ogóògłìó
(forty-money)
(c) ogóòtā + owó = *ogóòtāwó
(sixty-money)

From the schema in (13) above, we notice that all the number words from 'forty' to 'three thousand' are not similar in SY, YIN and YIT dialects of Yorùbá. They are derived through a multiplicative position and are expressed as a multiple of twenty (vigesimal). 'Forty' in SY, YIN and YIT is expressed as [ogóòđì] (ogún èjì i. e. ogún + ogún = ogóòđì̀, not ogún + èjì which can mean ogún-lé-èjì) $20 \times 2$ or 'two twenties'. Yorùbá language scholars are divided on the correct derivation of the numeral ogóògì 'forty'; while some of them like Bamgbose (1986: 23-27) believe that the derivation involves assimilation, vowel coalescence and vowel elision, others like Awobuluyi (1992: 62-66) believe it involves vowel elision and vowel 
harmony. The derivation of forty is similar to other numbers like [ogćòtā] $(20 \times 3)$, [ogóòrĩ] $(20 \times 4)$ and [ogćc̀rû́] $(20 \times 5)$. But what distinguishes YIT on these number words is vowel [0] which alternates with [o]. In SY and YIN, 'fifty' is [àádćtā] (i.e. 60 - $10=50$ ) and [èwádòta] (i. e. $60-10=50)$ respectively; however it is [maá lé nógóògì] $(10+40=50)$ in YIT. As shown in (16), this implies that the velar approximant [w] has been completely dropped in SY but it is retained in YIN, subsequently the process of vowel assimilation accounts for the /àá/ derivation.

Èwá $\rightarrow$ èá $\rightarrow \quad$ àá

In deriving the number words for 'fifty' [maá lé nógóòḑì] $(10+(20 \times 2)=50)$, 'seventy' [maá lé nógóòta] $(10+(20 \times 3)=70)$ and 'ninety' [maá lé nógóòré] $(10+(20 \times 4)=90)$, YIT again employs the additive position of base ten plus base twenty with other number units. We have already noted it that the additive number positions are simpler than the subtractive number positions. For the speakers of the YIT dialect of Yorùbá, the counting pattern that employs both the decimal and vigesimal bases is very attractive. 'One hundred': [ogćrṹ-ú] (SY)/[ogćòrú́] (YIN)/[ogóòrú] (YIT) is another basic number word in the three Yorùbá dialects.

'Two hundred' which is [igbā] in both SY and YIN is a basic number word, but YIT does not use [igbā], it uses [igbóo] as the number word for 'two hundred'. [igbā] and [igbóo] are not similar in terms of the consonant and vowel components; the former has two syllables and a $\mathrm{M}-\mathrm{M}$ tonal variation while the latter has three and a $\mathrm{M}-\mathrm{H}-\mathrm{M}$ tonal variation. We observe that, like YIT, no other Yorùbá dialect uses [igbóo] as the number word for 'two hundred' except İdáàtșà where we have [igbòó]. A close examination of YIT [igbóo] ('200') reveals that it is very likely to be derived from igba + owó, just like what we have in (14) above as the number word for 'thirty' [ćgbãwó]. In YIT igba + owó = igbóo, the vowel /a/ of the qualifying noun has been deleted, and then the velar approximant /w/ is completely dropped. To derive other higher numbers, YIT now continues to use [igbóo] ('200') as the additive number factor; in essence the dialect does not have basic numeral terms like [irĩwó] of SY or [irû́] of YIN, instead it continues the additive position of [igbóo méècjì] $(200 \times 2=400)$, [igbóo méta] $(200 \times 3=600)$, [igbóo mécr"́] $(200 \times 4=800)$, etc.

Aside from tonal variations and nasalized vowel, the three Yorùbá dialects under consideration have the same number words for 'one thousand' i. e. [Egbèrú̃] (SY), [Egbèrú] (YIN) and [egbèrú] (YIT). We again observe that most YIT number words end with oral vowels not with nasalized vowels; examples are shown in (17).

\begin{tabular}{|c|c|c|c|}
\hline English & $\begin{array}{l}\text { Standard } \\
\text { Yorùbá }\end{array}$ & Ifẹ̀ (Nigeria) YIN & Ifẹ̀ (Togo) YIT \\
\hline (5) Five & àrũ & غ̀rú́ & غ̀rú \\
\hline (15) Fifteen & méčćdógú́ & méc̀dogṹ & medógú \\
\hline (20) Twenty & ogṹ & ogṹ & ogú \\
\hline (30) Thirty & ogbõ & ogb ̃ & ćgbãwó \\
\hline (100) One Hundred & ogćrú́-ú & ogćòrû́ & ogóòrú \\
\hline
\end{tabular}


and Ifẹ̀ (Nigeria) Dialects of Yorùbá

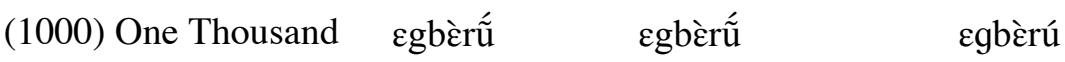

Table 17

We also find out in (13) above that the number words for 'two thousand' in SY and YIN i. e. [Egbàá/घgbèwá] (ẹgbàá mệàá) follow the pattern $200 \times 10=2000$ ('ten two hundreds'); ditto 'three thousand' [عgbèćdógṹ] (ẹgbàá mẹẹẹédógún) $200 \times 15=3000$ ('fifteen two hundreds'). In other words, SY and YIN take 'two hundred' as the basic number in the derivation of these higher numerals. But this is not the case in YIT, where 'two hundred' does not seem to be a basic number word. To derive 'two thousand' [ $\varepsilon$ gbrú méèdì] $1000 \times 2=2000$ ('two one thousands') and 'three thousand' [egbèrú méc̀tā] $1000 \times 3=3000$ ('three one thousands'), YIT uses 'one thousand' as the basic number word. So, instead of multiplying 200 by 10 to derive 2000, YIT only adds 1000 plus 1000 to derive 2000, etc. In essence, the most prominent compositional process which YIT employs among its numeral derivational techniques is addition to vigesimal and other units.

\section{Conclusion}

This study focuses the Yorùbá people of Benin and Togo who are indigenous to the Republics of Benin and Togo but by their origin, tradition and language, descent from Ilé-Ifẹ̀ in Nigeria. The study describes Ifẹ̀ (Togo and Benin) which is one of the dialects of these Yorùbá people living outside Nigeria. This study provides data and analysis on the vigesimal numerals in Ifẹ̀ (Togo), a Yorùbá dialect which has not been previously extensively surveyed, and compared it with the Standard Yorùbá and with Ifẹ̀ (Nigeria) which represents the language of Ilé-Ifẹ̀, the cradle of the Yorùbá race. In other words, this work represents a comparative numeral study of the Yorùbá language across three different Yorùbá dialects. There are many linguistic variations in the number words employed by Ifẹ̀ (Togo) and Ifẹ̀ (Nigeria) dialects of Yorùbá, such variations can be attributed to changes in time and distance. The two dialects (and the Standard Yorùbá which we also regard as a dialect) employ both addition to and subtraction from vigesimal as well as multiplication in numeral derivation. But Ifẹ̀ (Togo) favours the additive positions more than the subtractive and the multiplicative positions. In other words, higher numbers are frequently used as bases for addition not as bases for multiplication in Ifẹ̀ (Togo) dialect of Yorùbá. It is shown in this work that this phenomenon is a common feature in the speech of the present generation of speakers of the language, most especially elites and teenagers who try to avoid series of cognitive processes required in the derivation and comprehension of the Yorùbá number words.

\section{References}

Abraham, Roy C. (1958): Dictionary of Modern Yoruba. London.

Abimbola, Wande (1978): "The Yoruba Traditional Religion in Brazil: Problems and prospects". In: Oyelaran Olasope (ed.): Department of African Languages and Literatures Seminar Series I. Ile-Ife: Department of African Languages and Literatures, Obafemi Awolowo University: 1-64.

Adetugbọ, Abiodun (1967): "The Yoruba Language in Western Nigeria: Its Major Dialect Areas". PhD Dissertation, Columbia University.

Adetugbọ, Abiodun (1973): "The Yoruba Language in Yoruba History". In: Biobaku, Saburi O. (ed.): Sources of Yoruba History. Ibadan. 
Adewole, Lawrence O. (2007): Issues in Linguistics and Yoruba Language. Ile-Ife.

Awobuluyi, Oladele. (1992): "Aspect of Contemporary Standard Yoruva in Dialectological Perspective". In: Isola, Akinwumi (ed.): New Findings in Yoruba Studies. Ibadan: 5-79.

Awobuluyi, Oladele (1998): "Àwọn Èka-èdè Yorùbá' (Yorùbá Dialects)". Paper presented at the meeting of the Yorùbá Studies Association of Nigeria, November 24-26 1998, Ibadan.

Baloubi, Desire (2002): "From Nigeria to Benin: Introducing the Idaacha Dialect of Yoruba". In: Oyebade, Adebayo (ed.): The Transformation of Nigeria: Essays in Honour of Toyin Falola. Trenton NJ.

Bamgbose, Ayo (1986): Yoruba: A Language in Transition. Lagos.

Capo, Hounkpati B. C. (1980): "Defoid". In: Bendor-Samuel, John (ed.): The Niger-Congo Languages. Lenham: 275-290.

Crowder, Samuel A. (1843/1852): A Grammar of the Yoruba Language. London.

Ekundayo, Samuel A. (1986): Linguistics in the Service of Mankind. An Inaugural Lecture delivered at the University of Ife (now Obafemi Awolowo University) Ile-Ife. Ile-Ife.

Fábùnmi, Felix A. (2004): "The Status of Yorùbá Dialects in Communicative Competence and Language Proficiency". Africa Development 3: 103-113.

Fábùnmi, Felix A. (2009): İtúpalẹ Gírámà Yorùbá Mộộlí (A Grammatical Analysis of Yorùbá Mộộlí). Cape Town.

Hunt, Carl M. (1977): "Ọọ̣tunji Village: Yoruba Movement in America". PhD Dissertation, West Virginia University.

Igue, John/Yai, Olabiyi (1973): "The Yoruba-Speaking People of Dahomey and Togo". YORUBA Journal of the Yoruba Studies Association of Nigeria 1/1: 1-29.

Isola, Akinwumi (ed.) (1992): New Findings in Yoruba Studies. Ibadan.

Johnson, Samuel (1921): A History of the Yorubas. Lagos.

Koelle, Sigismund W. (1854/1963): Polyglotta Africana. Reprinted. London.

Lasebikan, Ebenezer L. (1963): "Yoruba in Brazil". West Africa 30: 352-64.

Oyetade, Benjamen A. (1996): "Comparative Number Words of Five Àkókó Dialects and Ẹdó with Standard Yorùbá". Journal of Nigerian Languages and Literatures 2: 17-46.

Raven, I. McDavid (1971): "Sense and Nonsense about American Dialects". In: Allen, Harold B. (ed.): Readings in American Dialectology. New York: 36-52.

Turner, Lorenze D. (1958): "The Role of Folklore in the Life of Yoruba of South Western Nigeria". In: Austin, William M. (ed.): Reports of the $9^{\text {th }}$ Annual Roundtable Meetings on Linguistics and Language Study. Georgetown: 45-57. ( = Monograph Series on Languages and Linguistics 12/12).

Williamson, Kay/Blench, Roger (2000): "Niger-Congo". In: Heine, Bernd/Nurse, Derek (eds.): African Languages: An Introduction. Cambridge. 